\title{
Ultrasonic Evaluation of Intact, Healing and Osteoporotic Long Bones
}

\author{
V. T. Potsika ${ }^{1}$, V. C. Protopappas ${ }^{1}$, K. N. Grivas ${ }^{2}$, T. V. Gortsas ${ }^{2}$, M. G. Vavva ${ }^{1}$, K. N. \\ Malizos $^{3}$, D. K. Polyzos ${ }^{2}$ and D. I. Fotiadis ${ }^{1,4, *}$
}

${ }^{1}$ Unit of Medical Technology and Intelligent Information Systems, Department of Materials Science and Engineering, University of Ioannina, GR 45110 Ioannina, Greece; e-mail: vpotsika@cc.uoi.gr; vprotop@cc.uoi.gr; mvavva@cc.uoi.gr

${ }^{2}$ Department of Mechanical Engineering and Aeronautics, University of Patras, GR 26500 Patras, Greece; e-mail: grivas@mech.upatras.gr; gortsas@mech.upatras.gr; polyzos@mech.upatras.gr

${ }^{3}$ Department of Medicine, School of Health Sciences, University of Thessaly, GR 41222

Larissa, Greece; e-mail:malizos@med.uth.gr

${ }^{4}$ Foundation for Research and Technology-Hellas, Institute of Molecular Biology and Biotechnology, Department of Biomedical Research, GR 45110 Ioannina, Greece; e-mail: fotiadis@cc.uoi.gr

*corresponding author

\begin{abstract}
Quantitative ultrasound (QUS) has been introduced in recent years for the comprehensive noninvasive and non-ionizing evaluation of bones. This paper presents a review of our research work of the last decade including experimental and computational studies for the ultrasonic assessment of fracture healing and osteoporosis. The axial transmission and the backscattering methods have been applied to investigate the variation of ultrasound velocity, the propagation of guided waves and the interaction of the complex scattering phenomena with bones. In the macrostructure level, computational models have been established mimicking healthy and pathologic bones, while the use of imaging modalities has opened new perspectives for the evaluation of the bone microstructure using QUS. In the nanostructure level, a deterministic hybrid model for bone healing and angiogenesis predictions under the presence of QUS has been established incorporating the spatiotemporal development of soft tissues, bone and the evolution of blood vessel network. The results reveal the promising monitoring potential of QUS and its positive impact on the acceleration of the bone healing process.
\end{abstract}

Keywords: Ultrasound, Long Bones, Guided Waves, Scattering, Fracture Healing, Osteoporosis

\section{Introduction}

Bone is a heterogeneous and hierarchically structured medium involving a network of cellular events which control the processes of bone maintenance, remodeling, and repair. The investigation of the material and microstructural changes which occur in osseous tissues due to 
bone pathologies, and more specifically osteoporosis and fracture healing, has attracted increasing attention by multidisciplinary research fields including medicine, biology and engineering. Osteoporosis is a skeletal disease which causes the thinning of the cortical cortex and reduction in bone mass provoking bone fragility and increasing the risk of fracture incidence. The main cause of osteoporosis is hormonal deficiency, and thus, the most frequent disease is post-menopausal osteoporosis. Approximately $40 \%$ of post-menopausal women over the age of 50 will suffer one or more fragility fractures, as well as $15-30 \%$ of men at a similar age as a result of particular hormonal disorders, chronic diseases or due to medication (Laugier and Haïat 2011). Osteoporotic fractures may reduce patients' quality of life, cause disability and even death, while the social and financial burden for the diagnosis, monitoring and treatment is tremendous. The diagnosis and monitoring of the pathology are mainly based on measurements of the bone mineral density using Dual energy X-ray Absorptiometry (DXA) scan, which is as a validated and reliable method. Nevertheless, it has several disadvantages as it includes X-ray exposure, it requires experienced radiology personnel, the equipment has a high purchase and maintenance cost and the precision of measurements may differ depending on the examined region. Additionally, even if X-ray measured bone mass provides information for bone fragility, it cannot reflect other important features like material strength or microstructure features. X-ray based techniques are also applied for the assessment of the fracture healing process as a wellestablished clinical standard. However, these techniques may be subjective according to the experience or clinical judgment of the orthopedic surgeon and can be unreliable for the assessment of bone healing.

Other methods focus on the assessment of bone mechanical properties either using mechanical testing by loading the whole bone and examining failure in compression, bending and torsion or via testing techniques such as microbeam, and micro and nanoindentation (Donnelly et al. 2011). Although these methods can provide significant information for the structural strength and material properties of bone from the macroscale to the nanoscale level, the specimen destruction during testing is a main disadvantage. Also, imaging techniques such as quantitative computed tomography (CT), high-resolution peripheral quantitative CT, highresolution magnetic resonance imaging (MRI), and micro-CT $(\mu-C T)$ are applied for the characterization of bone geometry and microarchitecture. Imaging modalities can provide a three-dimensional (3D) illustration of bone geometry and knowledge for tissue mineral density, but no information is derived related to bone strength. Concerning the assessment of tissue composition, it can be performed using scanning electron microscopy, vibrational spectroscopy, nuclear magnetic resonance imaging, and chemical and physical analytical techniques. These methods include measurements of the mineral density and crystallinity, elemental composition and collagen crosslink composition implying that for the complete material characterization the conduction of a biopsy is needed (Donnelly et al. 2011).

However, no one of the aforementioned methods can completely assess bone material and structural properties at different hierarchical levels, while in some cases the specimen has to be destructed during the experiment. In this direction, the use of advanced, non-destructive and non-invasive methods, which do not require exposure to ionizing radiation and provide quantitative information for the evolution of bone material and structural features, is considered as an open research field. Quantitative ultrasound (QUS) has emerged as a relative new and promising method for the evaluation of bone pathologies. The clinical significance of QUS for the evaluation of bone was highlighted in the 1950s via an ultrasonic method for the monitoring of fracture healing (Laugier and Haïat 2011). Nevertheless, QUS techniques were not popular before the 1990s due to immature technological infrastructure and limited knowledge on the complex interaction phenomena of ultrasonic propagation pathways and bone microstructure.

Several experimental and computational studies have been presented during the last few decades aiming to correlate QUS propagation parameters with bone defects as well as material 
and geometrical changes in pathological cases (Casciaro et al. 2015, Barbieri et al. 2011, Kaufman et al. 2007, Protopappas et al. 2006). Computational studies give insight to complicated wave propagation phenomena which cannot be investigated via traditional clinical and experimental procedures. Also, the assessment of bone is performed without the exposure of patients in experimental procedures, reducing thus human suffering, relative costs as well as time constraints. Nowadays, the rapid technological evolution has enhanced the exploitation of numerical means as powerful computational tools have been developed making efficient use of computation time, power and available memory. Simultaneously, imaging modalities have also evolved, and especially $\mu$-CT and scanning acoustic microscopy (SAM) which illustrate bone microstructure with an analysis down to the $\mu \mathrm{m}$ range leading to more realistic $2 \mathrm{D}$ and $3 \mathrm{D}$ numerical models (Rohde et al. 2014, Potsika et al. 2014, Moilanen et al. 2007).

For the ultrasonic evaluation of bone pathologies, the axial transmission technique is considered as the "gold standard" method. A single or multiple emitters and receivers are used aligned along the long axis of the bone in contact with the skin or directly with the bone (Foiret et al. 2014). The first arriving signal (FAS) velocity and attenuation have been used as the main quantitative parameters for bone characterization (Potsika et al. 2016a, Barbieri et al. 2011). However, when the wavelength is comparable to or smaller than the thickness of the cortex, the FAS propagates as a lateral wave reflecting only material and geometrical changes in the cortical surface. Thus, the propagation of guided waves has been also proposed as an advanced method which can capture microstructural alterations occurring at deeper bone layers (Foiret et al. 2014, Kilappa et al. 2014, Vavva et al. 2009). Ultrasonic axial transmission is widely applied along the axis of long bones such as the radius or tibia, while the through transmission and the backscattering methods have been used to a more limited extent and for different application sites. Through-transmission measurements require two transducers in opposite directions and are mainly applied to the heel bone (Kaufman et al. 2007, Barbieri et al. 2011). Devices using through-transmission at the distal radius are also available. The FAS velocity and attenuation, as well as the propagation of guided waves are the parameters of interest. On the other hand, in backscattering measurements a single transducer is used rendering this method more convenient for skeletal sites such as the hip and spine where through-transmission measurements are difficult to be conducted (Casciaro et al. 2015). Typical parameters of interest include the integrated reflection coefficient, the broadband ultrasound backscatter and apparent integrated backscatter (AIB), the time slope of apparent backscatter and the frequency slope of apparent backscatter which have been widely applied for the ultrasonic evaluation of cancellous bone (Liu et al. 2015, Hoffmeister et al. 2012, Karjalainen et al. 2012).

In this study, we present a comprehensive state of the art in the scientific domain of ultrasonic characterization of bone to highlight the significant diagnostic and monitoring potential of QUS in bone pathologies, as well as its positive impact on the acceleration of the bone healing process. Emphasis is given on the experimental and numerical studies of our research group over the last decade which investigate bone healing and osteoporosis evolution using QUS (Malizos et al. 2006, Protopappas et al. 2006, Protopappas et al. 2007, Vavva et al. 2008a, Potsika et al. 2014, Vavva et al. 2014, Vavva et al. 2015, Potsika et al. 2016a).

\section{Animal studies for the evaluation of bone healing using ultrasonic methods}

Several animal studies have been presented for the evaluation of bone healing using QUS methods which can be divided into two main categories according to their objective: (a) examine the bone status at a specific healing stage, (b) monitor the complete healing process.

Concerning the first category, in Floriani et al. (1967) an animal study on 40 guinea pigs with a femoral fracture was presented. The animals were sacrificed at the $6^{\text {th }}$ postoperative 
month and the bones were divided as: (a) completely healed, (b) partly healed, and (c) nonunions. Ultrasonic waves at $100 \mathrm{kHz}$ were applied and the velocity of propagation was measured. It was shown that for completely healed bones the velocity approximated the ratio $94 \%$ of the control value, while for partly healed bones and non-unions the corresponding ratio was $81 \%$ and $67 \%$ of the control value, respectively. In Abendschein and Hyatt (1972), a midfemoral graft model on 96 guinea pigs was used to examine the relation of ultrasound velocity with the modulus of elasticity of the healing bone. The animals were sacrificed 6 months postoperatively and the ultrasonic velocity was measured at $100 \mathrm{kHz}$ by positioning the transducers at the proximal and distal ends of the femoral shaft. Then, a three-point bending test was performed. It was found that the modulus of elasticity determined biomechanically was in linear relation with that determined by ultrasound. Another study on 36 rabbit tibiae fractures was presented by Gill et al. (1989) examining the correlation coefficient of the ultrasonic velocity with the load at failure, stiffness, and modulus of elasticity derived from the three-point bending test. Ultrasonic measurements were performed at 0.5 and $1 \mathrm{MHz}$ and higher correlation coefficients were found at $1 \mathrm{MHz}$. More recently, in Ferreira et al. (2010), the ability of ultrasound backscatter parameters in differentiating normal bones from bones with pseudarthorsis was investigated. A diaphyseal osteotomy of the femur was conducted for twelve young adult rats. Radiological study on the left forward limbs of all subjects was performed after a period of 120 days followed by euthanasia. An in vitro ultrasonic analysis of four bone samples with pseudarthrosis was realized with a 5-MHz circular transducer and the AIB was measured. Higher AIB values were found for pseudarthrosis comparing to normal bone.

Concerning the second category and the monitoring of the complete healing process, serial ultrasound measurements were performed on ulnar fractures in rabbits in Maylia et al. (1999), Saha et al. (1982), at successive postoperative weeks. The amplitude of the FAS was calculated and a healing index was proposed as the ratio of the amplitude from the healing limb to that from the contralateral. The healing index was found to increase linearly with the healing time. Additional in vitro experiments revealed that the proposed healing index was positively correlated with the bending strength of bone. More recently, Preininger et al. (2011) used quantitative SAM at $50 \mathrm{MHz}$ to evaluate microstructural and elastic changes of mineralized callus and cortical tissue in sheep tibiae subjected to a transverse osteotomy. The examined time periods were the $2^{\text {nd }}, 3^{\text {rd }}, 6^{\text {th }}$ and $9^{\text {th }}$ postoperative weeks with stabilization by either a rigid or a semi-rigid external fixator. It was shown that the stiffness increased while the porosity decreased in the callus during the healing process. Cortical porosity was found to increase at later healing stages while a gradual decrease of stiffness in cortical tissue was observed (Preininger et al. 2011). The findings revealed a different time-dependence according to the fixation type. In another study on 21 sheep (Barbieri et al. 2011), a model of a transverse middiaphyseal osteotomy of the tibiae was used to measure ultrasound propagation velocity and attenuation. The subjects were classified into three equal groups after 30, 60, and 90 days of healing and were finally sacrificed. Then, the ultrasound velocity and attenuation were measured at the osteotomy site in the transverse and longitudinal direction. The intact left sheep tibia was used for reference measurements. It was found that ultrasound propagation velocity increased, whereas broadband ultrasound attenuation decreased during the healing process, with significant differences between the periods of observation. In Rohrbach et al. (2013), a noninvasive monitoring system for fracture healing in small animals was presented. Specifically, a focused transmission system at $5 \mathrm{MHz}$ was applied in a 2-mm osteotomy of twelve-month-old female rats aiming to distinguish the early stages of fracture healing. Different healing stages after 6 weeks of consolidation were realized by different treatments and 2D projection images of time-of-flight, speed of sound and ultrasound attenuation were measured. It was shown that osteotomy gap regions filled with fibrous tissue have similar properties compared to adjacent muscle tissue. On the other hand, regions containing cartilage and mineralized callus tissue differed significantly (Rohrbach et al. 2013). 
In Protopappas et al. (2005) and Malizos et al. (2006), a system was proposed for the ultrasonic monitoring of fracture healing which was applied on a sheep tibial osteotomy with an external fixation device. The system consisted of a pair of miniature implantable ultrasound transducers, a wearable device and a centralized unit (Fig.1). The transmitter and receiver were positioned anterolaterally on each side of the osteotomy region with a distance of $25 \mathrm{~mm}$ among them and
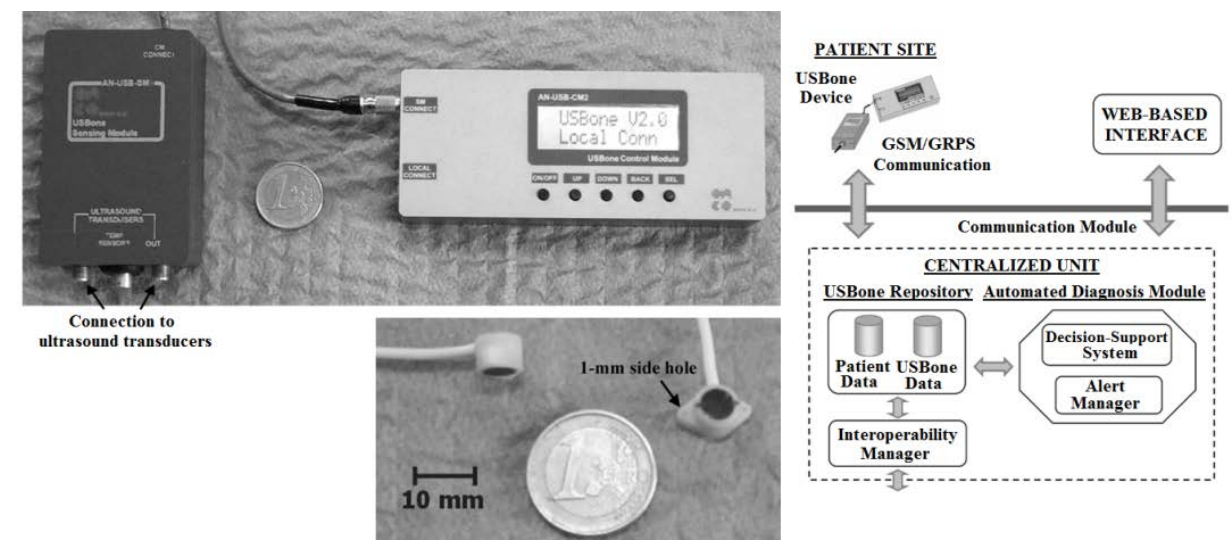

Fig. 1. Wearable system for the ultrasonic monitoring of bone healing (Protopappas et al. 2005)

ultrasound measurements were conducted at $1 \mathrm{MHz}$. Initially, velocity measurements for the intact bones were derived which were used as reference values. After the osteotomy, the assessment of the fracture healing progress proceeded on a 4-day basis until the $100^{\text {th }}$ postoperative day and the ultrasound velocity was measured for different healing stages. Fig.2 depicts the three different velocity evolution trends which were observed. The first was derived for 19 animals and radiographic examination revealed that this velocity tendency corresponds to secondary healing. In this group, the velocity initially decreased by an average $17 \%$ after the osteotomy and continued to decrease by a further $13 \%$ until the $38^{\text {th }}$ day. The results were attributed to the inflammatory response and the increased osteoclastic activity occurring at the early stages of secondary healing, which broaden further the fracture gap. Then, the velocity gradually increased reflecting the formation and consolidation of the callus. The second velocity pattern was observed for 3 animals showing a constant increase in velocity after the osteotomy. In this case, radiographic examination indicated the evolution of primary healing which leads to the direct bony union in the fracture region without the formation of callus. Concerning the third velocity tendency, 2 animals with non-unions were detected showing no systematic velocity variation profile. It was found also that the velocity of healed bones on the last postoperative day exceeds on average $80 \%$ the corresponding value of the intact bone. Then, the results were further analyzed to examine whether ultrasonic velocity could discriminate normal healing from non-healing bones with complications. It was observed that the velocity across bones that reached successfully bony union was higher than for those with complications even from the $50^{\text {th }}$ postoperative day. Thus, it was concluded that the ultrasound velocity could monitor a dynamic healing process and detect potential complications such as a non-union or pseudarthrosis at an early phase of the process. After animal euthanasia, bone densitometry and three-point bending were additionally performed. It was found that the measured velocity at the end of the follow-up period was significantly correlated with the square root of the Young modulus, the ultimate strength of the healing bones and callus density (Protopappas et al. 2005). However, the material and mechanical properties of healed bones reached lower values comparing to the reference values for intact bones. 


\section{Computational and theoretical studies using the axial transmission method}

\subsection{Fracture healing}

The ultrasonic evaluation of fracture healing using computational methods was initially based on the axial transmission technique (Dodd et al. 2007, Dodd et al. 2008, Protopappas et

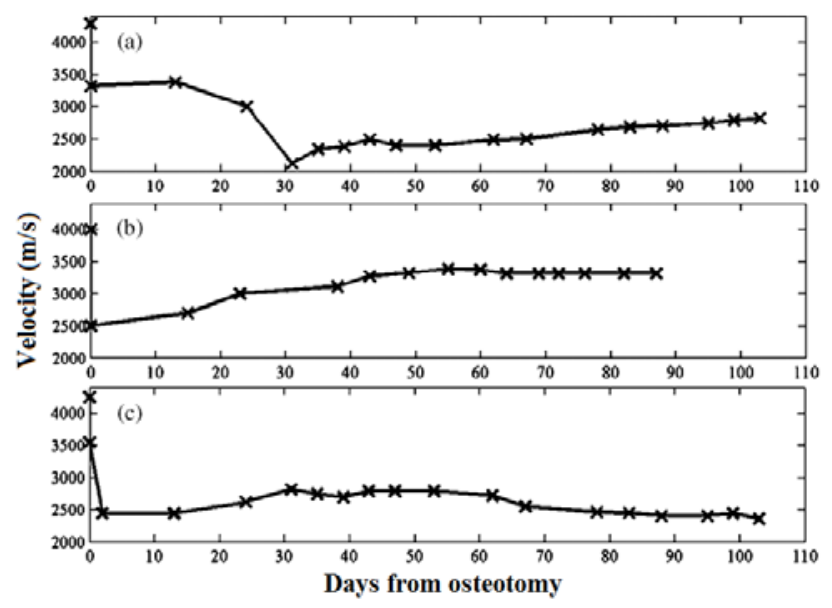

Fig. 2. Three velocity evolution patterns corresponding to: (a) secondary healing, (b) primary healing, and (c) delayed union (Protopappas et al. 2005)

al. 2006). In these studies, the cortical and callus tissues were simulated as $2 \mathrm{D}$, homogeneous and isotropic materials. More specifically, in (Dodd et al. 2007, Dodd et al. 2008) the axial transmission of ultrasonic waves at $200 \mathrm{kHz}$ was examined considering different geometries of fracture and healing stages. The FAS velocity and attenuation, as well as the ultrasound signal loss were calculated. Lower FAS velocity values were observed due to the fracture gap and an energy attenuation of the FAS due to wave propagation interaction phenomena which evolve in the discontinuity region. Also, it was shown that an oblique fracture leads to the reduction in the extra time delay of the propagating wave comparing to the transverse case and to the decrease of the signal amplitude (Dodd et al. 2007, Dodd et al. 2008). The angle of the oblique fracture was further investigated. It was found that by decreasing the fracture angle relative to the wave propagation direction, the extra time delay decreases and the signal loss increases. More recently, in (Machado et al. 2010) the compositional factors in fracture healing affecting ultrasound axial transmission were examined at $1 \mathrm{MHz}$, using four numerical daily-changing healing models, representing more realistic clinical conditions. The callus consisted of an evolving structure composed of six tissue types with different Young modulus and Poisson's ratio values including fibrous tissue, immature cartilage, mature cartilage, immature bone, intermediate bone and mature bone. The FAS velocity and energy attenuation were examined. A consistent FAS velocity increase was observed during callus consolidation for all the examined cases. Therefore, it was suggested that QUS may be an important clinical tool for the evaluation of bone healing reflecting callus degree of mineralization as well as consolidation delays and nonunions which may occur. However, it was observed that the FAS velocity is dependent only on superficial modifications in the propagation path, while callus composition could not well explain changes in energy attenuation (Machado et al. 2010).

In our first computational study (Protopappas et al. 2006), a 2D model of a bonemimicking plate was established and the healing process was simulated as a 7-stage process. 
Calculations of the FAS velocity were performed and the propagation of guided waves was also examined (Fig. 3). It was shown that the FAS velocity decreases during the first two healing stages and increases at later healing stages. Guided wave analysis was performed in the timefrequency (t-f) domain of the signal based on the Lamb wave theory. Three t-f distribution functions were studied: (a) the reassigned Spectrogram, (b) the smoothed-pseudo Wigner-Ville, and (c) the reassigned version of it. For intact bone, the S2, A3 Lamb modes were found to be the dominant waves for a $1 \mathrm{MHz}$ excitation frequency, while the S2, S0 at $0.5 \mathrm{MHz}$. During bone healing, the mechanical and structural callus properties affected the theoretical Lamb modes. Therefore, it was concluded that the study of the propagation of guided waves throughout the thickness of the cortical bone and the investigation of their sensitivity to both mechanical and structural changes during healing could provide supplementary qualitative information to velocity measurements and enhance the monitoring capabilities of QUS.

This study was later extended to account for the impact of boundary conditions on FAS velocity and guided wave propagation in 2D geometries of healing bones (Vavva 2008a). In particular, we simulated three different cases of fluid loading boundary conditions and examined their impact on the propagation features of guided waves and FAS velocity variation. In the first model, blood occupied the semi-infinite spaces of the upper and lower surfaces of the 2D cortical cortex. In the second model, the upper cortical surface was covered with a $2 \mathrm{~mm}$ layer of blood and the lower surface consisted of a semi-infinite fluid corresponding to bone marrow. In the third model, the upper bone surface was loaded by a $2 \mathrm{~mm}$ blood layer and the lower cortical surface consisted of a $2 \mathrm{~mm}$ bone marrow layer. The callus tissue incorporated different evolving ossification regions to simulate three successive bone healing stages. FAS velocity calculations were performed showing a decrease in the first stage and a gradual increase in stages 2 and 3 for the three examined boundary conditions. Also, it was observed that the application of different boundary conditions had a significant impact on the propagation of guided waves comparing to numerical models in which the cortical cortex is assumed free. Then, we used the same numerical model of callus in (Vavva et al. 2008b) to present a new method to conduct ultrasound velocity measurements by considering the transducers to be mounted on the pins of an already applied external fixation device instead of being implanted into the cortical cortex (Fig. 4). The objective of this study was to introduce a new technique which could offer several advantages in vivo compared to the previously described methods and evaluate its effectiveness. The method was first evaluated on intact bone models to derive reference values. Then, more realistic conditions were addressed by incorporating the callus tissue into the models. The effect of a possible non-perpendicular pin insertion was also examined considering five additional cases for different angles. The percutaneous and transosseous applications were also considered for comparison purposes. The variation of the FAS velocity was examined as a monitoring means of the fracture healing process. A FAS velocity increase was observed during the healing process. Nevertheless, only apparent velocity values could be derived from the proposed method corresponding to the whole propagation path (i.e. pins, bone and fracture) rather than to the fracture zone. This justified the increased velocity values which were found for all the examined cases. Therefore, it was concluded that the sensitivity of the method is limited and thus the identification of small alterations in the callus tissue during the fracture healing process is more difficult compared to other QUS transmission techniques. It was also shown that small inclination angles of the pins had a minor effect on the results indicating that the method could provide accurate results when applied invivo. 

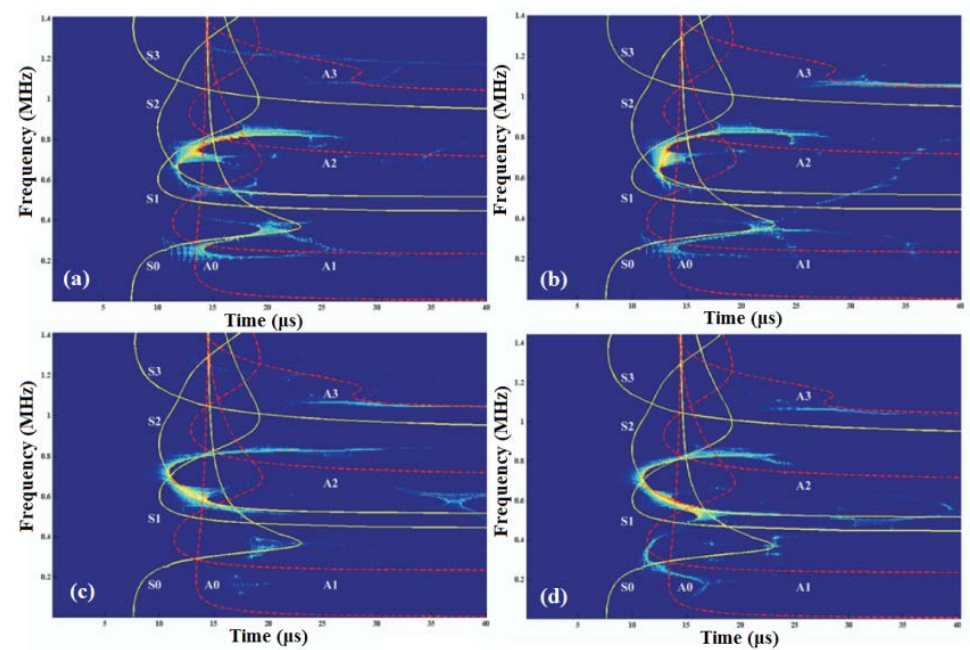

Fig. 3. Time-frequency representations of the signals (for 20-mm transducers' separation and 1 $\mathrm{MHz}$ excitation) obtained from the (a) first, (b) second (c) third, and (d) fifth healing stage of the 2D model in (Protopappas et al. 2006). Theoretical group velocity dispersion curves of the symmetric and antisymmetric Lamb modes are also superimposed on each t-f representation

More recently in (Potsika et al. 2014), we presented a theoretical and computational study based on an iterative effective medium approximation (IEMA) to investigate the evolution of the complex scattering propagation phenomena during fracture healing (Fig. 5). Realistic numerical models of healing long bones were developed incorporating the porous nature of callus with material and structural properties based on SAM images (Preininger et al. 2011). The imaging data represented 3-mm osteotomies in the right tibia of female Merino sheep and correspond to the $3^{\text {rd }}, 6^{\text {th }}$ and $9^{\text {th }}$ postoperative week. For the first time, wave dispersion and attenuation predictions were performed for the callus tissue and serial healing stages using IEMA. The propagation of guided waves was also examined for the central excitation frequencies 0.5 and $1 \mathrm{MHz}$. It was observed that both the attenuation coefficient and the group velocity corresponding to week 9 varied slightly with increasing the frequency in comparison to previous healing phases. This could be explained by the consolidation of the callus tissue at the final healing stages, followed by a gradual decrease of the scatterers' volume concentration and diameter. Thus, it was concluded that the effect of scattering, material dispersion and absorption phenomena is more significant during the early healing stages enhancing wave dispersion and attenuation predictions (Potsika et al. 2014). Guided wave analysis was also performed and revealed the gradual restoration of Lamb modes in week 9.

A 3D finite element study on guided wave propagation in intact and healing bones was also presented in (Protopappas et al. 2007). The fracture healing process was simulated considering three successive stages. The propagation of guided waves and the variation of the FAS velocity during bone healing were examined for a broadband 1-MHz excitation frequency. It was shown that the irregularity and anisotropy of the bone as well as the material and geometrical changes that take place during the healing process have a significant impact on the dispersion of guided waves. Concerning the FAS velocity, it was found to decrease in stage 1, remained the same up to stage 2, and then increased at stage 3. Nevertheless, when the FAS corresponded to a nondispersive lateral wave, its propagation velocity was almost unaffected by the elastic symmetry and geometry of the bone and could not characterize the callus tissue throughout its thickness (Protopappas et al. 2007). 


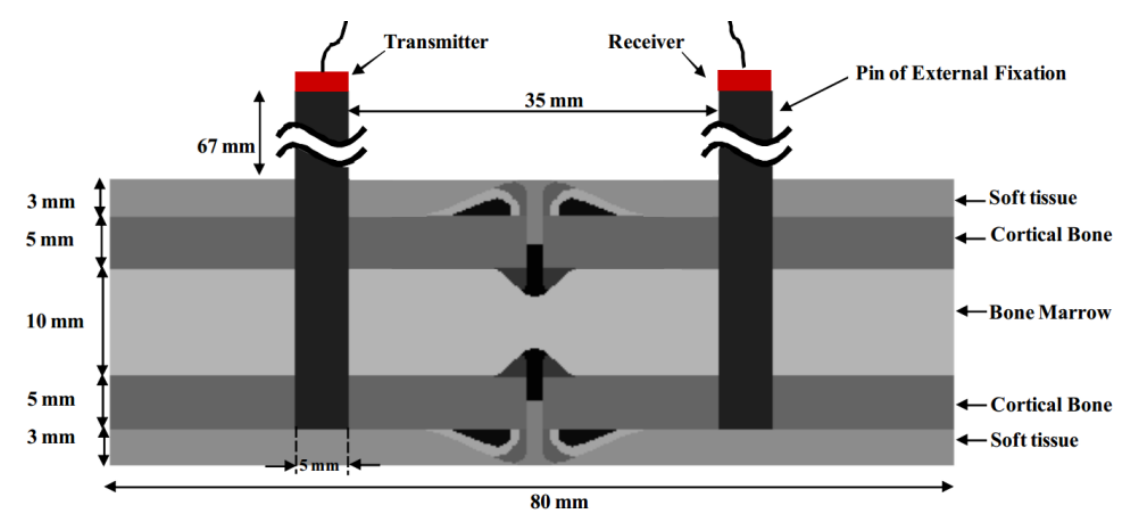

Fig. 4. The 2D model of a healing bone in which the external fixation pins and the transducers are also shown (Vavva et al. 2008b)
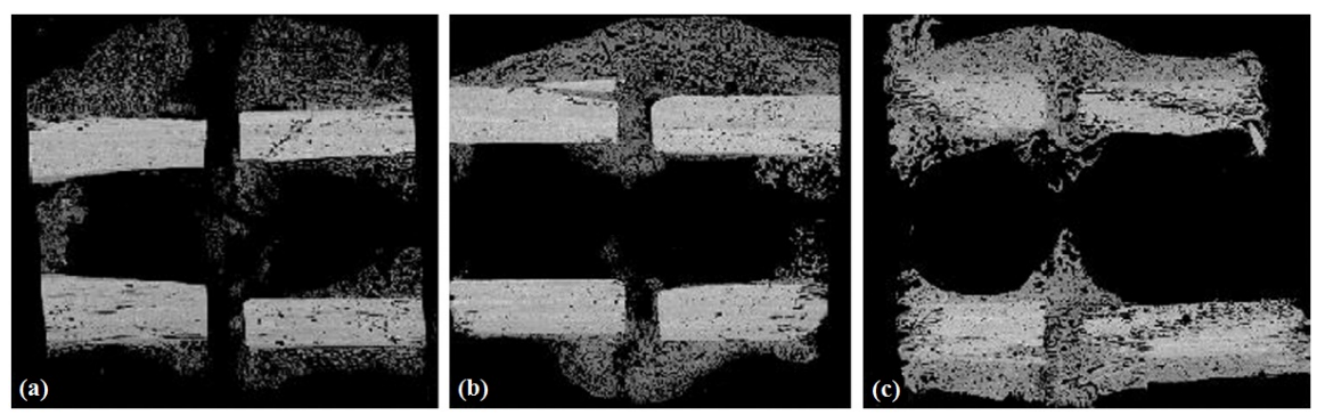

Fig. 5. Scanning acoustic microscopy images from a sheep osteotomy model representing the: (a) $3^{\text {rd }}$, (b) $6^{\text {th }}$ and (c) $9^{\text {th }}$ postoperative week (Potsika et al. 2014)

\subsection{Osteoporosis}

Several research groups have used numerical methods to investigate the interaction of ultrasound with osteoporotic bones and its potential to reveal changes in the cortical thickness and porosity (Rohde et al. 2014, Moilanen et al. 2007). Specifically, in (Nicholson et al. 2002, Bossy et al. 2002) the cortical bone was modeled as a linear elastic homogeneous plate and the potential of ultrasound to reflect the thinning of the cortical cortex in osteoporotic bones was examined through FAS velocity and guided wave analysis. X-ray computed tomography was used in (Moilanen et al. 2007) to establish more realistic 3D geometries of the human radius cortical bone and ultrasonically determine the thickness based on a guided wave analysis. Other numerical studies focus on the evaluation of cortical microstructure, porosity and anisotropy using QUS (Rohde et al. 2014, Grimal et al. 2013, Granke et al. 2011, Bourgnon et al. 2014). In (Rohde et al. 2014, Grimal et al. 2013) SAM images of the human femoral neck were used to study the interaction of ultrasound with cortical microstructure, porosity and thickness. FAS velocity calculations were performed and it was observed that: (a) the FAS velocity is sensitive to cortical porosity changes, while it is not affected by cancellous bone properties and the inhomogeneous nature of the cortical bone mineralized matrix, (b) the FAS velocity decreases as the porosity increases, while it increases as the cortical thickness and pores' diameter increase. A 3D micromechanical model was developed in (Granke et al. 2011) consisting of an 
anisotropic matrix with cylindrical pores to investigate the bone matrix and porosity. Porosity assessment using SAM was validated against Synchrotron Radiation $\mu$-CT measurements. A standard contact ultrasonic technique was applied to investigate the mesoscopic elastic coefficients. It was shown that, for the aged women, the elastic properties of the mineralized matrix do not indicate large variations among different samples. Also, it was reported that alterations of the intracortical porosity reflect most of the variations of mesoscopic elasticity, at least when the analyzed cortical porosity is large (Granke et al. 2011).

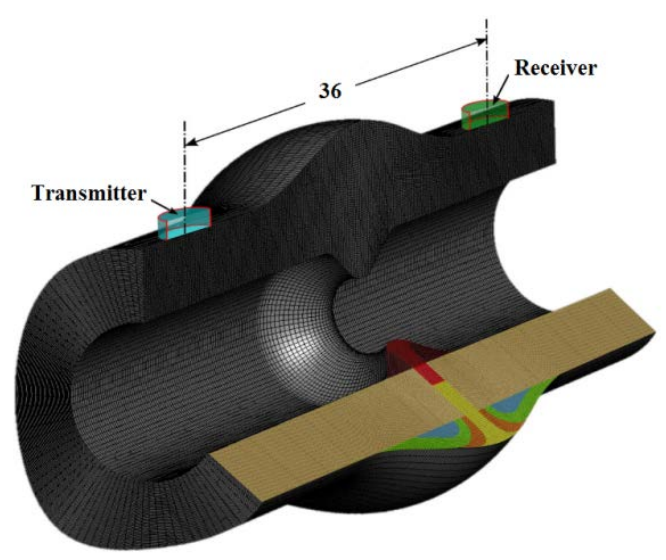

Fig. 6. 3D computational model of the diaphyseal segment of cortical bone incorporating the fracture callus and the transducers (Protopappas et al. 2007)

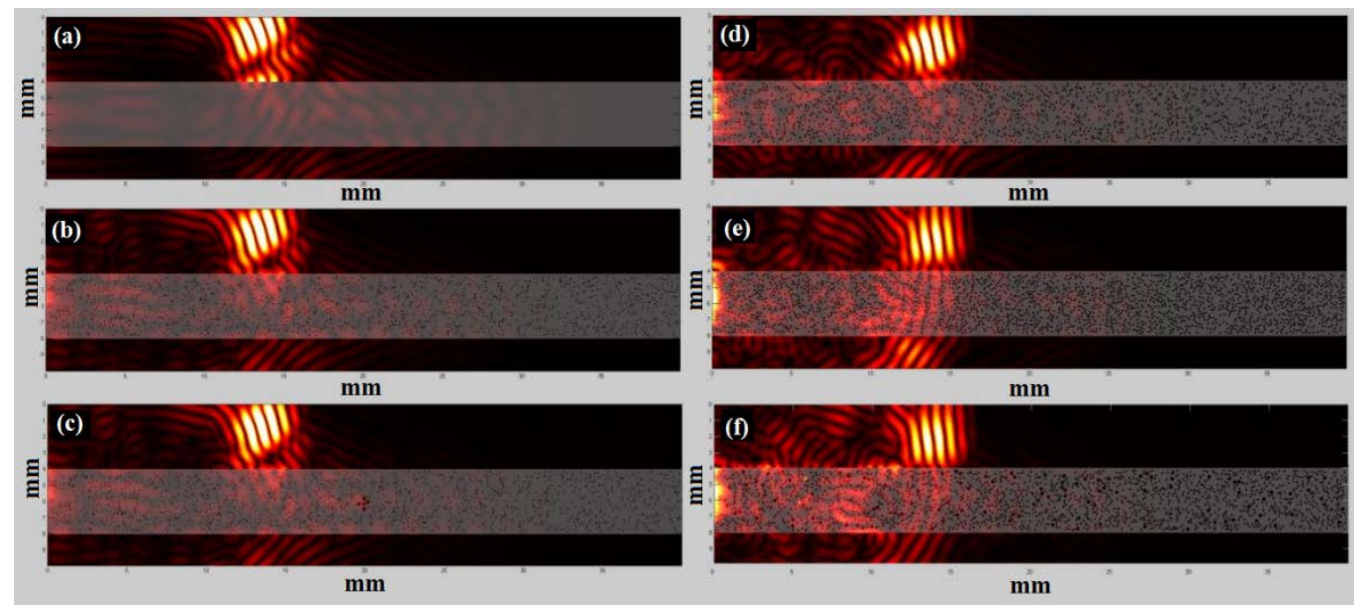

Fig. 7. Snapshots of wave propagation at $1 \mathrm{MHz}$ and time instant $10 \mu \mathrm{s}$ for the porosity scenarios: (a) $0 \%$, (b) $5 \%$, (c) $5 \%$ and 5 RL in the center of the plate, (d) $10 \%$, (e) $16 \%$ (f) $16 \%$ with different sizes of pores (Potsika et al. 2016a)

More recently, in (Potsika et al. 2016a) we presented a parametric and systematic computational study on ultrasound propagation in cortical bone models with different porosities. The effect of cortical porosity and the formation of large basic multicellular units, simply called non-refilled resorption lacunae (RL), on the FAS velocity was investigated considering small propagation paths. 2D computational models of cortical bone were developed 
incorporating different porosities and pore sizes mimicking normal and pathological cases. Emphasis was given on the identification of RL occurrence which may cause the thinning of the cortical surface and the increase of porosity at a later stage of osteoporosis. Compared to (Bourgnon et al. 2014), we extended the analysis from a small segment of cortical bone to the whole cortical cortex integrating more than a single RL. In addition, the gradual formation of osteoporosis was examined by considering concentrations of scatterers with larger diameters in the endosteal cortex and smaller pores in the periosteum. Non-contact transducers were positioned at a distance $2 \mathrm{~mm}$ above the cortical cortex using one source and multiple serial receivers. Axial transmission ultrasonic simulations were performed at 0.5 and $1 \mathrm{MHz}$. The local FAS velocity variation profile in small propagation paths was determined along the cortical cortex. It was concluded that: (a) the local FAS velocity can identify cortical porosity alterations and specifically changes in the number, size and position of the larger pores and (b) the excitation frequency $0.5 \mathrm{MHz}$ was more sensitive for the evaluation of cortical microstructure.

\subsection{Intact bone}

Most of the aforementioned numerical studies are based on the classical linear theory of elasticity. However, the classical elasticity cannot adequately describe bone's mechanical behavior since only homogeneous media and local stresses are considered which cannot effectively reflect the mechanical behavior of materials with microstructure in which the stress state has to be defined in a non-local manner (Vavva et al. 2009, Vavva et al. 2014). To this end, in (Vavva et al. 2009) we used the simplified Mindlin Form-II or dipolar gradient theory of elasticity for the determination of symmetric and antisymmetric modes propagating in a 2D and free of stresses gradient elastic plate. The main advantage of the proposed theory comparing to other couple stresses, micropolar, gradient elastic, and non-local elastic theories is its simplicity and the symmetry of all classical and non-classical stress tensors involved. More specifically, two terms were added in the constitutive equations representing the characteristic length in bone i.e.,: (a) the gradient coefficient g introduced in the strain energy, and (b) the micro-inertia term $h$, in the kinetic energy. The plate was considered free of stresses and double stresses. Two different values were examined for the micro-inertia term $\left(h=10^{-4} \mathrm{~m}\right.$ and $\left.\mathrm{h}=10^{-5} \mathrm{~m}\right)$. For each value three different combinations between $g$ and $h$ were assumed i.e., $g>h, g<h$, and $g=h$. The selection of these values was according to the osteon size. The velocity dispersion curves of guided waves were calculated and compared with the solutions derived from the Lamb wave theory (using the classical elasticity) to investigate the microstructural effects on guided modes. It was observed that when $g$ is not equal to $h$, cortical microstructure affects mode dispersion by inducing both material and geometrical dispersion. Thus, gradient elasticity could provide supplementary information to better understand guided waves in bones.

Nevertheless, for frequencies higher than $0.8 \mathrm{MHz}$, ultrasound propagates rather as a dispersive surface Rayleigh wave than a dispersive guided wave considering that the wavelengths are smaller than cortical thickness. Since the classical elasticity cannot support dispersion in bulk and Rayleigh waves we further extended our work in (Papacharalampopoulos et al. 2011) by applying the Mindlin's Form-II gradient elastic theory to examine the dispersion of Rayleigh waves in media with microstructure. The gradient elasticity was used along with the boundary element method (BEM) and the reassigned smoothed pseudo Wigner-Ville transform for the numerical determination of the dispersion curves of Rayleigh and guided waves propagating in a cortical bone model. More specifically, various cases of intrinsic parameters were examined that serve as a means for investigating the dispersive nature of the Rayleigh wave and its relationship with the intrinsic parameters of the Form-II gradient elasticity. Then, BEM simulations were performed for a free of stresses cortical plate with intrinsic parameters according to (Ben-Amoz 1976). The transducers' distance was set to 60 
$\mathrm{mm}$. The results demonstrated the efficiency of gradient elasticity to describe Rayleigh wave dispersion along the bone surface.

More recently, in (Vavva et al. 2014), the role of microstructural effects was considered by incorporating four intrinsic parameters in the stress analysis. The examined cases correspond to the three different combinations between the gradient coefficient $\mathrm{c}$ and the microinertia term $\mathrm{h}$ in the dipolar elasticity examined in (Georgiadis et al. 2004). Calculations were performed for the cases: (a) case 1: $\mathrm{l}_{1}=\mathrm{l}_{2}=\mathrm{h}_{1} \neq \mathrm{h}_{2}\left(\mathrm{l}_{1}=1.04 \times 10^{-4} \mathrm{~m}, \mathrm{l}_{2}=1.04 \times 10^{-4} \mathrm{~m}\right.$, $\left.\mathrm{h}_{1}=1.04 \times 10^{-4} \mathrm{~m}, \mathrm{~h}_{2}=0.74 \times 10^{-4} \mathrm{~m}\right)$, (b) case $2: \mathrm{l}_{1}=\mathrm{h}_{1}, \mathrm{l}_{2}=\mathrm{h}_{2}\left(\mathrm{l}_{1}=1.04 \times 10^{-4} \mathrm{~m}, \mathrm{l}_{2}=0.74 \times 10^{-4} \mathrm{~m}\right.$, $\left.\mathrm{h}_{1}=1.04 \times 10^{-4} \mathrm{~m}, \mathrm{~h}_{2}=0.74 \times 10^{-4} \mathrm{~m}\right)$, (c) case $3: \mathrm{l}_{1}=\mathrm{l}_{2}=\mathrm{h}_{2} \neq \mathrm{h}_{1}\left(\mathrm{l}_{1}=0.74 \times 10^{-4} \mathrm{~m}, \mathrm{l}_{2}=0.74 \times 10^{-4} \mathrm{~m}\right.$, $\left.\mathrm{h}_{1}=1.04 \times 10^{-4} \mathrm{~m}, \mathrm{~h}_{2}=0.74 \times 10^{-4} \mathrm{~m}\right)$, (d) case $4: \mathrm{l}_{2}=\mathrm{h}_{1}=\mathrm{h}_{2} \neq \mathrm{l}_{1}\left(\mathrm{l}_{1}=1.04 \times 10^{-4} \mathrm{~m}, \mathrm{l}_{2}=0.74 \times 10^{-4} \mathrm{~m}\right.$, $\left.\mathrm{h}_{1}=0.74 \times 10^{-4} \mathrm{~m}, \mathrm{~h}_{2}=0.74 \times 10^{-4} \mathrm{~m}\right)$, (e) case $5: \mathrm{l}_{1}=\mathrm{h}_{1}=\mathrm{h}_{2} \neq \mathrm{l}_{2}\left(\mathrm{l}_{1}=0.74 \times 10^{-4} \mathrm{~m}, \mathrm{l}_{2}=1.04 \times 10^{-4} \mathrm{~m}\right.$, $\left.\mathrm{h}_{1}=0.74 \times 10^{-4} \mathrm{~m}, \mathrm{~h}_{2}=0.74 \times 10^{-4} \mathrm{~m}\right)$, and (f) case $6: \mathrm{l}_{1}=\mathrm{l}_{2}, \mathrm{~h}_{1}=\mathrm{h}_{2}\left(\mathrm{l}_{1}=0.74 \times 10^{-4} \mathrm{~m}, \mathrm{l}_{2}=0.74 \times 10^{-4} \mathrm{~m}\right.$, $\left.\mathrm{h}_{1}=1.04 \times 10^{-4} \mathrm{~m}, \mathrm{~h}_{2}=1.04 \times 10^{-4} \mathrm{~m}\right)$. The group and phase velocity dispersion curves were calculated and compared with existing computational results and semi-analytical curves for a simpler case of Rayleigh waves in dipolar gradient elastic half-spaces as illustrated in Fig. 8. Comparisons were also presented with the velocity of the first-order antisymmetric mode propagating in a dipolar plate in order to investigate the Rayleigh asymptotic behavior (Vavva et al. 2014). For a transmitter-receiver distance $60 \mathrm{~mm}$, the semi-analytical frequency-group velocity dispersion curves of the Rayleigh wave in both Mindlin's Form II gradient and classical elasticity were converted to t-f curves and were superimposed on the t-f plane of the corresponding signals obtained from the BEM model in (Papacharalampopoulos et al. 2011).
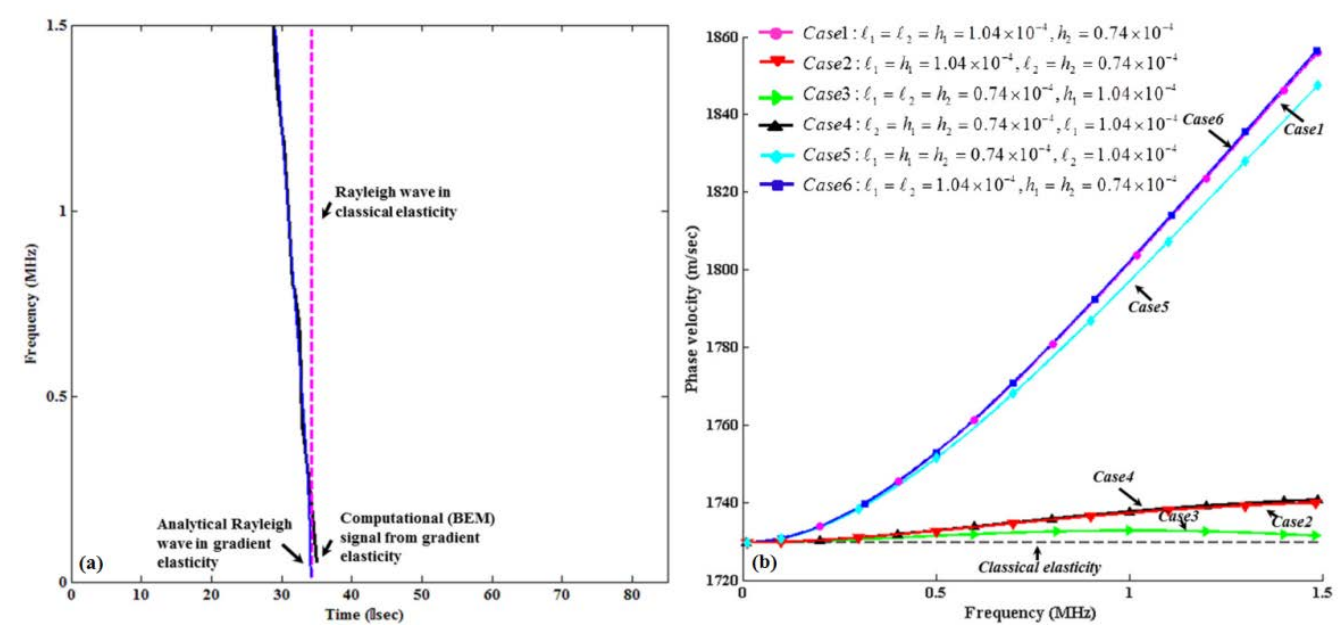

Fig. 8. (a) Time-frequency representation of the analytically derived Rayleigh wave for case 1. The corresponding computational signal of (Papacharalampopoulos et al. 2011) is also shown as well as the curve that corresponds to the classical elastic theory, (b) phase velocity dispersion of the Rayleigh wave analytically derived for the cases $1,2,3,4,5$, and 6 . The classical elastic case is also presented with the dotted line (Vavva et al. 2014)

The t-f representation of the analytically derived Rayleigh wave for that case is illustrated in (Fig. 8a). Except for the very low frequency range, the agreement between BEM simulations and theoretical results from gradient elasticity was perfect. Also, it was found that Mindlin's Form II gradient elasticity can effectively describe the dispersive nature of Rayleigh waves. 


\section{Computational studies using the backscattering method}

\subsection{Osteoporosis}

Two main factors contribute to ultrasonic attenuation in bone: absorption and scattering. Scattering phenomena are stimulated in composite media such as bone as a result of the interplay of an ultrasonic wave with the particles if their material properties are different from those of the surrounding medium.

The evaluation of ultrasonic scattering in cancellous bone has been widely investigated experimentally (Liu et al. 2015, Karjalainen et al. 2012, Malo et al. 2014). The main parameters of interest are the broadband ultrasonic backscatter, the apparent backscatter coefficient, the AIB and the frequency slope of apparent backscatter. Also, numerical and theoretical scattering models have been established to evaluate the effect of frequency and microstructural properties on the backscatter coefficient. The Faran cylinder model considered solid cylinders embedded in fluid to simulate the heterogeneity of cancellous bone (Laugier and Haïat 2011). The relation of the backscatter coefficient with frequency and cancellous thickness was investigated. Then, this model was modified assuming a lattice structure of regularly-spaced parallel trabeculae, trabeculae positioned sufficiently randomly and trabeculae positioned quasi-periodically (Kitamura et al. 1998, Kitamura et al. 1996, Wear 1999, Ta et al. 2008). In (Mézière et al. 2014), 3D numerical models were developed representing clusters of ellipsoidal scatterers randomly distributed in water. Finite-difference simulations were performed to study ultrasonic propagation in anisotropic porous media. Various configurations were applied to measure velocities and attenuation coefficients of the ensemble-averaged transmitted wave. As in real cancellous bone, one or two longitudinal modes were detected, depending on the microstructure features. The results were compared with two basic theoretical approaches: (a) Biot's theory, and (b) the Independent Scattering Approximation (ISA) which is a classical first-order approach of multiple scattering theories. However, when only one longitudinal wave was observed and for porosities higher than $90 \%$, the ISA successfully predicted the attenuation coefficient, as well as negative dispersion. This was not the case in the Biot's theory (Mézière et al. 2014).

On the other hand, few computational studies have investigated the potential of scattering measurements to reflect changes in cortical microstructure. In (Gortsas et al. 2015, Iori et al. 2015, Bourgnon et al. 2014), the backscattering method was used to evaluate the variation of scattering phenomena due to the interaction of ultrasound with various microstructural models. Different porosities and pore sizes were considered to simulate normal and pathological cases. However, these studies are at a preliminary stage and focus on the identification of the formation of non-refilled basic multicellular units based on SAM data. Specifically, in (Gortsas et al. 2015) we presented a $2 \mathrm{D}$ numerical study to evaluate the potential of ultrasonic backscattering to capture alterations in cortical porosity and discriminate the appearance of RL. A plane wave at $1 \mathrm{MHz}$ was considered to simulate wave propagation and investigate scattering evolution in 2D models of cortical bone with porosities from $0-16 \%$. The occurrence of pores larger than the Haversian canals was also examined. The magnitude of the radial scattering amplitude and the displacement at a distance of $20 \mathrm{~mm}$ above the cortical cortex in the backward direction were calculated. It was reported that the scattering amplitude and the evaluation of displacements induced by the scattered energy in the backward direction convey significant information about changes in porosity and the formation of RL.

\subsection{Fracture healing}

The ultrasonic evaluation of fracture healing using the backscattering method is a relative new research field with open perspectives. In Section 2, the experimental study of (Ferreira et al. 
2010) was described in which the backscattering method was used to discriminate normal bone from bone with pseudarthrosis. More recently in (Potsika et al. 2016b), we presented simulations of ultrasound propagation in healing long bones using the BEM to investigate the monitoring potential of backscattering parameters. The callus was modeled as a $2 \mathrm{D}$, inhomogeneous medium consisting of the different ossification regions presented in (Protopappas et al. 2007) with evolving material properties. The interaction of a plane wave at $100 \mathrm{kHz}$ with healing long bones was investigated by calculating the acoustic pressure and scattering amplitude in the backward direction. Multiple receivers were placed at a distance 20 $\mathrm{mm}$ above the cortical cortex to provide an acoustic pressure pattern along the bone cortex. The distance between two serial receivers was $2 \mathrm{~mm}$. The scattering amplitude was also calculated from 0-180 degrees. It was shown that the acoustic pressure and the scattering amplitude in the backward direction could potentially reflect changes in material and geometrical features of the callus tissue and contribute to the monitoring of the fracture healing process. However, further experimental and computational research is required.

\section{Ossification process and angiogenesis predictions in bone healing under the ultrasound effect}

From a biological point of view, fracture healing is a complex process involving specific regenerative patterns and a sequence of cellular actions and interactions, regulated by biochemical and mechanical signals. The occurrence of a fracture is followed by the formation of a hematoma in the gap region due to blood vessel disruption. The hematoma consists of cells from both peripheral and intramedullary blood, as well as bone marrow cells (Marsell and Einhorn 2011). Bone regeneration is achieved when specific mesenchymal stem cells are recruited, proliferate and differentiate into osteogenic cells (Marsell and Einhorn 2011). Thus, stem cells approach the fracture region and endothelial cells migrate and proliferate forming new vessels. Angiogenesis plays significant role in bone healing since it re-establishes blood circulation at the fracture region which limits ischaemic necrosis and enhances bone repair. Several growth factors such as the transforming growth factor (TGF), bone morphogenetic protein (BMP), fibroblast growth factor (FGF), and vascular endothelial growth factor (VEGF) regulate the vascularization process having direct or indirect osteogenic and angiogenic influence (Vavva et al. 2015). However, the VEGF pathway is considered to be the key regulator in the neoangiogenesis and revascularization of the fracture region.

The effect of ultrasound on fracture healing mechanisms has been investigated experimentally in (Reher et al. 1999, Doan et al. 1999). More specifically, these studies examined the impact of ultrasound on human mandibular osteoblasts, gingival fibroblasts and peripheral blood mononuclear cells. Various ultrasound application techniques, intensities and frequencies were examined. It was observed that in all cases the cytokines that are related with angiogenesis were highly stimulated in osteoblasts, and the VEGF levels were increased. Also, in (Cheung et al. 2011) the effect of ultrasound on osteoporotic fracture rat models led to the increase in the VEGF. Thus, it has been found that ultrasound plays a key role on the proliferation of osteoblasts via osteocytes and enhances blood vessel formation due to alterations in the transport of VEGF and fibroblast growth factor which are related to angiogenesis.

Computational studies in the field of bone mechanobiology have also been presented aiming to provide insight to the evolution of cell activities and angiogenesis mechanisms during the fracture healing process (Shefelbine et al. 2005, Claes and Heigele 1999). In a more recent study (Peiffer et al. 2011), sprouting blood vessel growth and branching were simulated. Nevertheless, these models do not account for the effect of ultrasound on the fracture healing 
mechanisms and angiogenesis. To this end, in (Vavva et al. 2015), we presented a deterministic hybrid model for bone healing and angiogenesis predictions under the impact of ultrasound. The proposed mathematical model was based on the model of (Peiffer et al. 2011) extended by: (a) including an additional equation describing the spatiotemporal evolution of ultrasound acoustic pressure, and (b) modifying the equation that describes the spatiotemporal evolution of VEGF. Processes of the normal fracture healing evolution such as intramembranous and endochondral ossification were integrated in the model. Then, numerical simulations were performed for different values of the newly introduced parameters aiming to provide comprehensive knowledge on the cellular mechanisms that accelerate bone healing due to ultrasound. In Fig. 9,

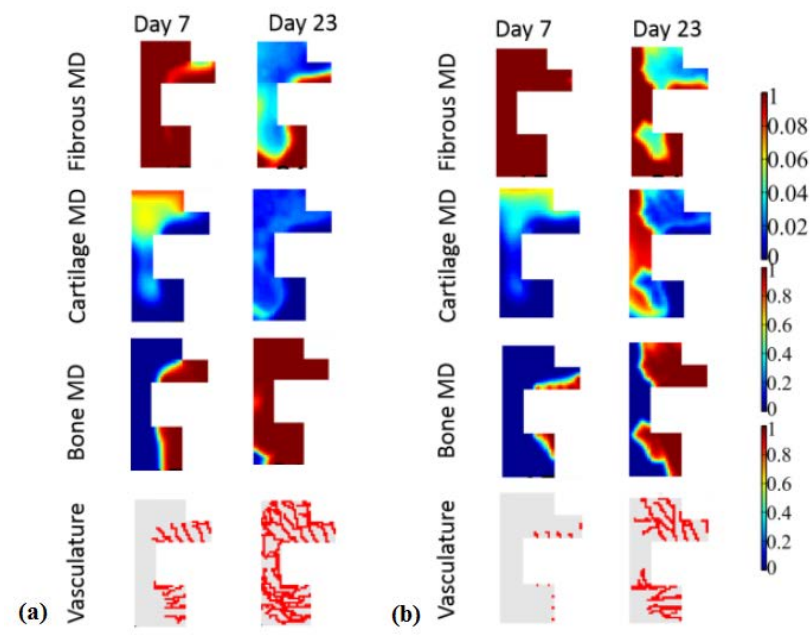

Fig. 9. Spatiotemporal evolution of fibrous tissue, cartilage and bone matrix density: (a) under the presence of ultrasound, (b) without the presence of ultrasound (Vavva et al. 2015).

the evolution of the tissue density in the callus during normal healing with and without the presence of ultrasound is shown. It was observed that the application of ultrasound causes the upregulation in VEGF expression in weeks 3 and 4 after the fracture occurrence which is in agreement with previous experimental findings (Reher et al. 1999, Doan et al. 1999, Cheung et al. 2011). Therefore, ultrasound enhances blood vessel growth and the proposed model could be useful for the ultrasonic characterization of the biological processes evolving in fracture healing.

\section{Discussion}

The evaluation of intact, osteoporotic and healing bones using quantitative ultrasonic methods has been addressed in several experimental, computational and theoretical studies over various levels ranging from macrostructure to nanostructure. Different ultrasound configurations have been applied including the axial, through and backscattering method and various quantitative and qualitative parameters have provided promising results for bone evaluation such as the first arriving signal velocity and attenuation, the propagation of guided waves, the scattering amplitude and the apparent integrated backscatter. During the last decade, our research group has presented extensive and intensive research work using different ultrasonic methods, numerical approaches and imaging data which are summarized in Table I. 
Several experimental studies have been conducted using QUS to monitor the fracture healing process and detect complications such as pseudarthrosis and non-unions. It was found that ultrasound propagation velocity increases, while the broadband ultrasound attenuation decreases as the healing process evolves (Floriani et al. 1967, Barbieri et al. 2011, Protopappas et al. 2005). Specifically, in (Protopappas et al. 2005) we demonstrated that velocity measurements after 100 days of a sheep osteotomy exceed on average $80 \%$ the corresponding intact bone value, while in (Floriani et al. 1967) measurements at the $6^{\text {th }}$ postoperative month on guinea pigs revealed that for completely healed bones the velocity approximated the ratio 94\% of the intact bone, respectively. Concerning the early detection of complications, we showed in (Protopappas et al. 2005) that the velocity across bones which finally reached bony union was higher than for those with complications even from the $50^{\text {th }}$ postoperative day. Additionally, the study of (Ferreira et al. 2010) on pseudarthrosis in rats showed that AIB values for pseudarthrosis were higher comparing to intact bone. This tendency was attributed to the complex matrix composition of fibrous tissue, cartilage and calcified points with different acoustic impedance. Moreover, a smaller attenuation and reflection in pseudarthrosis compared to bone permits a high penetration of acoustic energy in water sample interface. However, in this study comparisons of the backscattering parameters for a successful healing process with the incidence of pseudarthrosis were not included. The relation of ultrasonic velocity with the mechanical properties of bone was also investigated in (Abendschein and Hyatt 1972, Gill et al. 1989, Protopappas et al. 2005). We showed in (Protopappas et al. 2005) that the propagation velocity at late healing stages is highly correlated with the square root of the Young modulus, the ultimate strength of the healing bones and the density of the callus. On the other hand, a three-point bending test on rabbit tibiae in (Gill et al. 1989) followed by regression analysis failed to reveal a sufficiently good correlation between ultrasonic velocity measurements and the bending properties of healing bones. However, it is difficult to make direct comparisons between these studies and provide reference velocity and attenuation values for each phase of healing as they use different animal species, fracture characteristics, distances between the transducers, frequencies and follow-up periods. Also, the treatment is another factor that may vary as according to (Rohrbach et al. 2013) without further treatment, the 2-mm rat osteotomies would lead to delayed healing. Nevertheless, even for the same study and specimens, different treatments can be used. Finally, different thresholds for the detection of the FAS velocity or approximations for the calculation of the signal attenuation have an impact on the results.

\begin{tabular}{|c|c|c|c|}
\hline Author & Type of study & $\begin{array}{l}\text { Ultrasonic } \\
\text { Method, } \\
\text { Frequency }\end{array}$ & Aim of study \\
\hline $\begin{array}{l}\text { Protopappas et al. } \\
\text { 2005, } \\
\text { Malizos et al. } \\
2006\end{array}$ & $\begin{array}{l}\text { Experimental, } \\
\text { fracture healing }\end{array}$ & $\begin{array}{l}\text { Axial, } \\
1 \mathrm{MHz}\end{array}$ & $\begin{array}{l}\text { Serial velocity measurements. Comparison to } \\
\text { radiographic, densitometric and mechanical } \\
\text { evaluation. }\end{array}$ \\
\hline $\begin{array}{l}\text { Protopappas et al. } \\
2006\end{array}$ & $\begin{array}{l}\text { 2D numerical, } \\
\text { fracture healing }\end{array}$ & $\begin{array}{l}\text { Axial, } \\
0.5 \& 1 \mathrm{MHz}\end{array}$ & $\begin{array}{l}\text { FAS velocity calculations and guided wave } \\
\text { analysis. }\end{array}$ \\
\hline $\begin{array}{l}\text { Protopappas et al. } \\
2007\end{array}$ & $\begin{array}{l}\text { 3D numerical, } \\
\text { fracture healing }\end{array}$ & $\begin{array}{l}\text { Axial, } \\
1 \mathrm{MHz}\end{array}$ & $\begin{array}{l}\text { Effect of the geometry and anisotropy of } \\
\text { healing bones on the FAS velocity and guided } \\
\text { wave propagation. }\end{array}$ \\
\hline $\begin{array}{l}\text { Vavva et al. } \\
\text { 2008a }\end{array}$ & $\begin{array}{l}\text { 2D numerical, } \\
\text { fracture healing }\end{array}$ & $\begin{array}{l}\text { Axial, } \\
1 \mathrm{MHz}\end{array}$ & $\begin{array}{l}\text { Effect of boundary conditions on FAS } \\
\text { velocity and guided wave propagation. }\end{array}$ \\
\hline $\begin{array}{l}\text { Vavva et al. } \\
2008 b\end{array}$ & $\begin{array}{l}\text { 2D numerical, } \\
\text { fracture healing }\end{array}$ & $\begin{array}{l}\text { Axial, } \\
1 \mathrm{MHz}\end{array}$ & $\begin{array}{l}\text { Ultrasound velocity calculations on healing } \\
\text { bones using the external fixation pins. }\end{array}$ \\
\hline $\begin{array}{l}\text { Vavva et al. 2009, } \\
\text { Vavva et al. } 2014\end{array}$ & $\begin{array}{l}\text { Theoretical, } \\
\text { bone-mimicking }\end{array}$ & - & $\begin{array}{l}\text { Velocity dispersion of guided waves } \\
\text { propagating in a free gradient elastic plate. }\end{array}$ \\
\hline
\end{tabular}




\begin{tabular}{|c|c|c|c|}
\hline & $\begin{array}{l}\text { plates with } \\
\text { microstructure }\end{array}$ & & $\begin{array}{l}\text { Application to cortical bone. } \\
\text { Rayleigh wave dispersion in bone according } \\
\text { to Mindlin’s Form II gradient elasticity. }\end{array}$ \\
\hline $\begin{array}{l}\text { Papacharalampo- } \\
\text { poulos et al. } 2011\end{array}$ & $\begin{array}{l}\text { 2D numerical, bone- } \\
\text { mimicking plates } \\
\text { with microstructure }\end{array}$ & $\begin{array}{l}\text { Axial, } \\
1.57 \mathrm{MHz}\end{array}$ & $\begin{array}{l}\text { Analysis of the Rayleigh and guided waves in } \\
\text { cortical bone according to Mindlin's Form II } \\
\text { gradient elastic theory. }\end{array}$ \\
\hline $\begin{array}{l}\text { Potsika et al. } \\
2014\end{array}$ & $\begin{array}{l}\text { Theoretical \& 2D } \\
\text { numerical based on } \\
\text { SAM images, } \\
\text { fracture healing }\end{array}$ & $\begin{array}{l}\text { Axial, } \\
0.3,0.5 \& 1 \\
\mathrm{MHz}\end{array}$ & $\begin{array}{l}\text { Wave dispersion and attenuation coefficient } \\
\text { predictions using an iterative effective } \\
\text { medium approximation. Guided wave } \\
\text { analysis in 2D models of healing bones. }\end{array}$ \\
\hline Vavva et al. 2015 & $\begin{array}{l}\text { 2D numerical, } \\
\text { fracture healing }\end{array}$ & - & $\begin{array}{l}\text { Bone healing and angiogenesis predictions } \\
\text { under the effect of ultrasound. Spatiotemporal } \\
\text { evolution of fibrous tissue, cartilage and bone } \\
\text { matrix density. }\end{array}$ \\
\hline $\begin{array}{l}\text { Gortsas et al. } \\
2015\end{array}$ & $\begin{array}{l}\text { 2D numerical, } \\
\text { osteoporosis }\end{array}$ & $\begin{array}{l}\text { Backscattering, } \\
1 \mathrm{MHz}\end{array}$ & $\begin{array}{l}\text { Potential of scattering ultrasound to detect } \\
\text { changes in cortical porosity and discriminate } \\
\text { the occurrence of RL. }\end{array}$ \\
\hline $\begin{array}{l}\text { Potsika et al. } \\
\text { 2016a }\end{array}$ & $\begin{array}{l}\text { 2D numerical, } \\
\text { osteoporosis }\end{array}$ & $\begin{array}{l}\text { Axial, } \\
0.5 \& 1 \mathrm{MHz}\end{array}$ & $\begin{array}{l}\text { Effect of cortical porosity and RL occurrence } \\
\text { on FAS velocity. }\end{array}$ \\
\hline $\begin{array}{l}\text { Potsika et al. } \\
\text { 2016b }\end{array}$ & $\begin{array}{l}\text { 2D numerical, } \\
\text { fracture healing }\end{array}$ & $\begin{array}{l}\text { Backscattering, } \\
0.1 \mathrm{MHz}\end{array}$ & $\begin{array}{l}\text { Potential of the acoustic pressure and } \\
\text { scattering amplitude to assess the fracture } \\
\text { healing process. }\end{array}$ \\
\hline
\end{tabular}

Table 1. Summary of our research work on ultrasonic evaluation of intact and pathologic bones approximations for the calculation of the signal attenuation have an impact on the results

Also, numerical modeling has provided new insights for the ultrasonic assessment of bone allowing the researcher to visualize the propagation of ultrasound through the composite bone microstructure and providing new knowledge on the complex wave propagation phenomena which cannot be observed experimentally. Another advantage of numerical studies is the setup and optimization of the transducers system and signal characteristics without the need to perform the equivalent experiment which is time and cost consuming. Finally, difficulties in obtaining bone specimens and the experimental artifacts associated with ultrasonic measurements can be avoided. Our research group has presented an extensive numerical research work to study the variation of the FAS velocity and the propagation of guided waves at different healing stages using the axial transmission method (Protopappas et al. 2006, Protopappas et al. 2007, Vavva et al. 2008a, Vavva et al. 2008b). These studies revealed that the FAS velocity increases during the fracture healing process. However, when the FAS wave corresponds to a lateral wave, the velocity reflects material and geometrical changes of the upper callus tissue surface. To this end, we also investigated the propagation of guided waves. The dispersion of velocity and guided wave features were strongly influenced by the irregular geometry and anisotropy of the osseous, callus and surrounding soft tissues. Then, in (Potsika et al. 2014), we presented more realistic numerical models of healing long bones which account for callus porosity and inhomogeneous nature based on SAM images. Wave dispersion and attenuation predictions were performed for the callus at different healing stages. A negative dispersion was exhibited in the frequency range $24-1200 \mathrm{kHz}$. It was reported that the role of scattering, material dispersion and absorption phenomena is more significant during the early healing stages enhancing wave dispersion and attenuation estimations. More recently, in (Potsika et al. 2016b) we used the backscattering method to study the variation of the acoustic pressure and scattering amplitude in healing bones. This work presented two new quantitative parameters aiming to provide new knowledge on the complex scattering phenomena evolving during fracture healing, but further experimental and numerical research is needed. SAM images derived from a well-characterized set of human tibia samples were also presented in 
(Raum et al. 2014) revealing that the progression of bone deterioration in elderly patients results in an accumulation of large RLs, cortical thinning and changes in the tissue stiffness. To this end, in (Gortsas et al. 2015, Potsika et al 2016a) we investigated the potential of QUS to detect changes in cortical porosity focusing on the occurrence of RLs at an early stage of osteoporosis. Ultrasonic axial transmission revealed that: (a) the FAS velocity decreases with the increase of cortical porosity which is in agreement with (Rohde et al. 2014), and (b) serial FAS velocity measurements from multiple receivers can detect the occurrence of larger pores depending on the frequency. Ultrasonic backscattering showed that the scattering amplitude decreases with increasing porosity, but the presence of a cluster of few larger pores had no significant impact on the calculated values (Gortsas et al. 2015).

Although several computational studies have investigated the underlying mechanisms of cell activities and angiogenesis (Shefelbine et al. 2005, Peiffer et al. 2011), in Vavva et al. (2015) we presented a bioregulatory model which accounts for the effect of ultrasound on angiogenesis and bone healing mechanisms. Ultrasound was modeled to primarily affect VEGF transport. It was shown that QUS plays a significant role in angiogenesis and leads to accelerated completion of blood vessel network. Thus, the proposed mathematical model could be a useful tool for the prediction of the treatment outcome, early diagnosis of complications and monitoring of fracture healing. Nevertheless, further investigation is needed to draw safe conclusions and determine which scenarios of QUS affected mechanisms are more plausible.

Therefore, QUS methods can play a key role in diagnosis and monitoring of bone pathologies. The appropriate interpretation of experimental and numerical findings at different hierarchical levels of bone structure could provide new knowledge on the complex wave propagation phenomena and healing mechanisms evolving at different healing stages. However, despite the extensive experimental and numerical research work especially during the last two decades, clinical trials are required before the application of QUS in daily clinical practice.

\title{
7. Conclusions
}

This work highlighted the outstanding diagnostic and monitoring role of quantitative ultrasound in osteoporosis and fracture healing as well as its positive effect on the acceleration of the healing process and especially angiogenesis. We presented a review of experimental and numerical findings of our research group within the last decade compared to the milestone studies in the literature. It was shown that multiscale modeling of bones will be a key trend in the management of pathologies and will dominate research in this field in the future.

Извод

\section{Ултразвучна процена здравих, зарастајућих и остеопорозних дугих костију}

\author{
V. T. Potsika ${ }^{1}$, V. C. Protopappas ${ }^{1}$, K. N. Grivas ${ }^{2}$, T. V. Gortsas ${ }^{2}$, M. G. Vavva ${ }^{1}$, K. N. \\ Malizos $^{3}$, D. K. Polyzos' ${ }^{2}$ D. I. Fotiadis ${ }^{1,4^{*}}$ \\ ${ }^{1}$ Unit of Medical Technology and Intelligent Information Systems, Department of Materials \\ Science and Engineering, University of Ioannina, GR 45110 Ioannina, Greece; \\ имејл: vpotsika@сc.uoi.gr; vprotop@cc.uoi.gr; mvavva@cc.uoi.gr
}


${ }^{2}$ Department of Mechanical Engineering and Aeronautics, University of Patras, GR 26500

Patras, Greece;

имејл: grivas@mech.upatras.gr; gortsas@mech.upatras.gr; polyzos@mech.upatras.gr

${ }^{3}$ Department of Medicine, School of Health Sciences, University of Thessaly, GR 41222

Larissa, Greece;

имејл: malizos@med.uth.gr

${ }^{4}$ Foundation for Research and Technology-Hellas, Institute of Molecular Biology and

Biotechnology, Department of Biomedical Research, GR 45110 Ioannina, Greece;

имејл: fotiadis@cc.uoi.gr

* главни аутор

\section{Резиме}

Последњих година, квантитативни ултразвук (QUS) се уводи за потребе неинванзивне и нејонизујуће процене стања костију. У овом раду, представљен је преглед наших истраживања у последњих десет година који укључује експерименталне и компјутерске студије за ултразвучну процену зарастања фрактура и остеопорозе. Коришћене су методе аксијалне трансмисије и методе повратног одбијања како би се испитале промене ултразвучне брзине, ширење вођених таласа и интеракција комплексног феномена повратног одбијања са костима. На нивоу макроструктуре, развијени су компјутерски модели који имитирају здраву и болесну кост, док употреба снимака отвара нове перспективе за процену коштане микроструктуре уз помоћ квантитативног ултразвука. На нивоу наноструктуре, развијен је детерминистички хибридни модел за зарастање костију и предвиђање ангиогенезе у присуству квантитативног ултразвука који укључује просторни и временски развој меких ткива, костију и процену мреже крвних судова. Резултати указују на обећавајућу улогу квантитативног ултразвука у праћењу као и његов позитивни утицај на бржи процес зарастања костију.

Кључне речи: ултразвук, дуге кости, вођени таласи, повратно одбијање, зарастање, остеопороза.

\section{References}

Abendschein W F and Hyatt G W (1972). Ultrasonics and physical properties of healing bone, J. Trauma, 12(4), 297-301.

Barbieri G, Barbieri CH, Mazzer B, Péla A (2011). Ultrasound Propagation Velocity and Broadband Attenuation Can Help Evaluate the Healing Process of an Experimental Fracture, J. Orthop. Res., 29, 444-451.

Ben-Amoz M (1976). A dynamic theory for composite materials, J.Appl. Math. Ph. 27, 83-99.

Bossy E, Talmant M, Laugier P (2002). Effect of bone cortical thickness on velocity measurements using ultrasonic axial transmission: a 2d simulation study, J. Acoust. Soc. Am., 112, 297-307.

Bourgnon A, Sitzer A, Chabraborty A, Rohde K, Varga P, Wendlandt R, Raum K (2014). Impact of microscale properties measured by $50-\mathrm{MHz}$ acoustic microscopy on mesoscale elastic and ultimate mechanical cortical bone properties. Proc. IEEE International Ultrasonics Symposium, Chicago, IL, USA, 636-638. 
Casciaro S, Conversano F, Pisani P, Muratore M (2015). New perspectives in echographic diagnosis of osteoporosis on hip and spine, Clin. Cases Min. \& Bone Metab., 12(2), 142150 .

Cheung WH, Chow SK, Sun MH, Qin L, Kwok-Sui L (2011). Low-Intensity Pulsed Ultrasound Accelerated Callus Formation, Angiogenesis and Callus Remodeling in Osteoporotic Fracture Healing. Ultr. Med. Biol., 37(2), 231-238.

Claes L and Heigele C (1999). Magnitudes of local stress and strain along bony surfaces predict the course and type of fracture healing, J. Biomech, 32(3), 255-266.

Doan N, Reher P, Meghji S, Harris M (1999). In vitro effects of therapeutic ultrasound on cell proliferation, protein synthesis, and cytokine production by human fibroblasts, osteoblasts, and monocytes, J Oral Maxillofac Surg., 57, 409-419.

Dodd SP, Cunningham JL, Miles AW, Gheduzzi S, Humphrey VF (2008). Ultrasound transmission loss across transverse and oblique bone fractures: an in vitro study, Ultrasound in Med. \& Biol., 34(3), 454-462.

Dodd SP, Miles AW, Gheduzzi, Humphrey VF, Cunningham JL (2007). Modelling the effects of different fracture geometries and healing stages on ultrasound signal loss across a long bone fracture, Comp. Meth. Biomec. Biomed. Eng.,10(5), 371-375.

Donnelly E (2011). Methods for Assessing Bone Quality, Clin. Orthop. Relat. Res., 469, 21282138.

Ferreira ML, Matusin DP, Machado CB, Silva PC, Mello NB, Amara AC, Franco RS, de Albuquerque Pereira W C, Schanaider A (2010). Characterization of pseudarthrosis with ultrasound backscattered signals in rats, Acta Cirúrgica Brasileira, 25 (1), 13-17.

Floriani LP, Debervoise NT, Hyatt GW (1967). Mechanical properties of healing bone by use of ultrasound, Surg. Forum, 18, 468-470.

Foiret J, Minonzio J G, Chappard C, Talmant M, Laugier P (2014). Combined Estimation of Thickness and Velocities Using Ultrasound Guided Waves: A Pioneering Study on In Vitro Cortical Bone Samples, IEEE Trans. on Ultras., Ferroel., and Freq. control, 61(9), 14781488.

Georgiadis HG, Vardoulakis I, Velgaki EG (2004). Dispersive Rayleigh-wave propagation in microstructured solids characterized by dipolar gradient elasticity, J. Elasticity, 74, 17-45.

Gill PJ, Kernohan G, Mawhinney IN, Mollan RA, McIlhagger R (1989). Investigation of the mechanical properties of bone using ultrasound, Proc. Inst. Mech. Eng.,203, 61-63.

Gortsas T, Grivas K N, Polyzos D, Potsika VT, Protopappas VC, Fotiadis DI, Raum K (2015). The effect of cortical bone porosity on ultrasonic backscattering parameters, Proc. 6th Europ. Symp. Ultras. Charact. Of Bone, Corfu, Greece.

Granke M, Grimal Q, Saïed A, Nauleau P, Peyrin F, Laugier P (2011). Change in porosity is the major determinant of the variation of cortical bone elasticity at the millimeter scale in aged women, Bone, 49, 1020-1026.

Grimal Q, Rohrbach D, Grondin J, Barkmann R, Gluer CC, Raum K, Laugier P (2013). Modeling of femoral neck cortical bone for the numerical simulation of ultrasound propagation. Ultrasound Med. Biol., 40, 1-12.

Hoffmeister BK, Wilson AR, Gilbert MJ, Sellers ME (2012). A backscatter difference technique for ultrasonic bone assessment, J. Acoust. Soc. Am., 132(6), 4069-4076.

Iori G, Raum K, Potsika VT, Fotiadis DI, Gortsas T (2015). High-frequency cortical backscatter reveals cortical microstructure - a simulation study, Proc. 6th Europ. Symp. Ultras. Charact. Of Bone, Corfu, Greece.

Karjalainen JP, Riekkinen O, Töyräs J, Hakulinen M, Kröger H, Rikkonen T, Salovaara K, Jurvelin J S (2012). Multi-site bone ultrasound measurements in elderly women with and without previous hip fractures, Osteoporos. Int., 23, 1287-1295.

Kaufman JJ, Luo G, Siffert RS (2007). A portable real-time ultrasonic bone densitometer, Ultrasound in Med. \& Biol., 33 (9), 1445-1452. 
Kilappa A, Xu K, Moilanen P, Heikolla E, Ta D, Timonen J (2013). Assessment of the fundamental flexular guided wave in cortical bone by an axial-transmission array transducer, Ultrasound in Med. \& Biol., 39(7), 1223-1232.

Laugier P and Haïat G (2011). Bone quantitative ultrasound. Springer Dordrecht Heidelberg London New York: Science+Business Media B.V.

Liu C, Zhang R, Li Y, Xu F, Ta D, Wang W (2015). An Ultrasonic Backscatter Instrument for Cancellous Bone Evaluation in Neonates, Engineering, 1(3), 336-343.

Machado CB, de Albuquerque Pereira WC, Talmant M, Padilla F, Laugier P (2010). Computational evaluation of the compositional factors in fracture healing affecting ultrasound axial transmission measurements, Ultrasound in Med. \& Biol., 36(8), 13141326.

Malizos KN, Papachristos AA, Protopappas VC, Fotiadis DI (2006). Transosseous application of low-intensity ultrasound for the enhancement and monitoring of fracture healing process in a sheep osteotomy model, Bone, 38, 530-539.

Malo MKH, Töyräs J, Karjalainena JP, Isakssonc H, Riekkinena O, Jurvelin JS (2014). Ultrasound backscatter measurements of intact human proximal femurs-Relationships of ultrasound parameters with tissue structure and mineral density, Bone, 64, 240-245.

Marsell R and Einhorn TA (2011). The biology of fracture healing (2011). Injury, 42(6), 551555.

Maylia E and Nokes LD (1999). The use of ultrasonics in orthopaedics-A review, Technol. Health Care, 7(1), 1-28.

Mézière F, Muller M, Bossy E, Derode A (2014). Measurements of ultrasound velocity and attenuation in numerical anisotropic porous media compared to Biot's and multiple scattering models, Ultrasonics, 54 (5), 1146-1154.

Moilanen P, Talmant M, Nicholson PHF, Cheng S, Timonen J, Laugier, P (2007). Ultrasonically determined thickness of long cortical bones: Three-dimensional simulations of in vitro experiments, J. Acoust. Soc. Amer., 122, 2439-2445.

Nicholson P, Moilanen P, Kärkkäinen T, Timonen J, Cheng S (2002). Guided ultrasonic waves in long bones: modelling, experiment and application, Physiol. Meas., 23, 755-768.

Papacharalampopoulos A, Vavva MG, Protopappas VC, Fotiadis DI, Polyzos D (2011). A numerical study on the propagation of Rayleigh and guided waves in cortical bone according to Mindlin's Form II gradient elastic theory, J. Acoust. Soc. Am., 130(2), 10601070.

Peiffer V, Gerisch A, Vandepitte D, Van OH, Geris L (2011). A hybrid bioregulatory model of angiogenesis during bone fracture healing, Biomech. Model. Mechanobiol., 10, 383-395.

Potsika VT, Grivas KN, Gortsas T, Iori G, Protopappas VC, Raum K, Polyzos D, Fotiadis DI (2016). Computational Study of the Effect of Cortical Porosity on Ultrasound Wave Propagation in Healthy and Osteoporotic Long Bones, Materials, 9(3), 1-21.

Potsika VT, Grivas KN, Gortsas T, Protopappas VC, Polyzos D, Fotiadis DI (2016). Boundary element simulation of ultrasonic backscattering during the fracture healing process, Proc. 38th An. Intern. Conf. IEEE Engin. Med. Biol. Soc., Orlando, Florida USA.

Potsika VT, Grivas KN, Protopappas VC, Vavva MG, Raum K, Rohrbach D, Polyzos D, Fotiadis DI (2014). Application of an effective medium theory for modeling ultrasound wave propagation in healing long bones, Ultrasonics, 54, 1219-1230.

Preininger B, Checa S, Molnar FL, Fratzl P, Duda GN, Raum K (2011). Spatial-temporal mapping of bone structural and elastic properties in a sheep model following osteotomy, Ultrasound in Med. \& Biol., 37(3), 474-483.

Protopappas VC, Baga DA, Fotiadis DI, Likas AC, Papachristos AA, Malizos KN (2005). An Ultrasound Wearable System for the Monitoring and Acceleration of Fracture Healing in Long Bones, IEEE Trans. Biomed. Engin., 52(9), 1597-1608. 
Protopappas VC, Fotiadis DI, Malizos KN (2006). Guided ultrasound wave propagation in intact and healing long bones, Ultrasound in Med. \& Biol., 32(5), 693-708.

Protopappas VC, Kourtis IC, Kourtis LC, Malizos KN, Massalas C V, Fotiadis D I (2007). Three-dimensional finite element modeling of guided ultrasound wave propagation in intact and healing long bones, J. Acoust. Soc. Am., 121(6), 3907-3921.

Raum K, Grimal Q, Varga P, Barkmann R, Glüer CC, Laugier P (2014). Ultrasound to Assess Bone Quality, Curr Osteoporos Rep, 12, 154-162.

Reher P, Doan N, Bradnock B, Meghji S, Harris M (1999). Effect of ultrasound on the production of IL-8, basic FGF and VEGF. Cytokine, 11, 416-423.

Rohde K, Rohrbach D, Gluer CC, Laugier P, Grimal Q, Raum K, Barkmann R (2014). Influence of Porosity, Pore Size, and Cortical Thickness on the Propagation of Ultrasonic Waves Guided Through the Femoral Neck Cortex: A Simulation Study, IEEE Trans. Ultras. Ferroel. Freq. Control, 61, 302-313.

Rohrbach D, Preininger B, Hesse B, Gerigk H, Perka C, Raum K (2013). The early phases of bone healing can be differentiated in a rat osteotomy model by focused transversetransmission ultrasound, Ultrasound in Med. \& Biol., 39(9), 1642-1653.

Saha S, Rao VV, Malakanok V, Albright JA (1982). Quantitative measurement of fracture healing by ultrasound, Proc. 1st Southern Biomed. Eng. Conf., 247-249.

Shefelbine SJ, Augat P, Claes L, Simon U (2005). Trabecular bone fracture healing simulation with finite element analysis and fuzzy logic, J. of Biomechanics, 38, 2440-2450.

Vavva MG, Gergidis LN, Protopappas VC, Charalampopoulos A, Polyzos D, Fotiadis DI (2014). A study on Rayleigh wave dispersion in bone according to Mindlin's Form II gradient elasticity, J. Acoust. Soc. Am., 135(5), 3117-3126.

Vavva MG, Grivas KN, Polyzos D, Fotiadis DI, Carlier A, Geris L, Van OH (2015). A Mathematical model for bone healing predictions under the ultrasound effect, Proc. 6th Europ. Symp. Ultras. Charact. Of Bone, Corfu, Greece.

Vavva MG, Protopappas VC, Fotiadis DI, Malizos KN (2008b). Ultrasound Velocity Measurements on Healing Bones Using the External Fixation Pins: A Two-Dimensional Simulation, J. Serb. Soc. Comp. Mech., 2(2), 1-15.

Vavva MG, Protopappas VC, Gergidis LN, Charalampopoulos A, Fotiadis DI, Polyzos D (2008a). The effect of boundary conditions on guided wave propagation in twodimensional models of healing bone, Ultrasonics, 48, 598-606.

Vavva MG, Protopappas VC, Gergidis LN, Charalampopoulos A, Fotiadis DI, Polyzos D (2009). Velocity dispersion of guided waves propagating in a free gradient elastic plate: Application to cortical, J. Acoust. Soc. Am., 125(5), 3414-3427. 